\title{
The Analysis of Unsignalized Intersection Road Performance at Manukan Wetan Surabaya City
}

\author{
Muhan Fahri Irzadi ${ }^{1}$, Sri Wiwoho Mudjanarko², Ikhsan Setiawan ${ }^{3}$, Joewono Prasetijo ${ }^{4}$, \\ Hary Moetriono ${ }^{5}$ \\ Narotama University ${ }^{123}$, Universiti Tun Hussein Onn Malaysia ${ }^{4}$, \\ 17 Agustus 1945 University Surabaya ${ }^{5}$ \\ mfi23051998@gmail.com¹, sri.wiwoho@narotama.ac.id², \\ ikhsan.setiawan@narotama.ac.id ${ }^{3}$, joewono@uthm.edu.my ${ }^{4}$,nono.harmoet@gmail.com
}

\begin{abstract}
Surabaya is the capital of the province of East Java and is the second largest city in Indonesia after Jakarta. As a city that will continue to develop, the mobility of the people is getting higher, as well as the progress of the current means of transportation which is increasing, causing traffic problems, one of which occurs at intersections. One of the intersections that will be reviewed is the Raya Manukan intersection. This study uses the MKJI 1997 guideline, with primary data collection by means of traffic conditions survey and secondary collection, namely data on the number of vehicle growth from the Department of Population and Civil Registry of Surabaya City. This study aims to determine the performance of the unsigned intersection at the Raya Manukan intersection. With this research data, as well as from the results of traffic analysis at the Raya Manukan intersection with the boundary from the Amd Street Intersection to the Buntaran Street Intersection. From the calculation results, it is obtained that the intersection capacity is $3750.9 \mathrm{pcu} / \mathrm{hour}$, with a degree of saturation value of 0.8254 . From the results of the analysis, the calculations that have been carried out have not been able to reach the desired degree of saturation value, which is as suggested by MKJI 1997.Therefore then an alternative is made with road widening engineering and produces a saturation degree value of 0.7493 , so that the road widening on Raya Manukan Kulon is the best alternative in solving the capacity problem of Intersection Manukan.
\end{abstract}

Keywords: Performance, Unmarked Intersections, MKJI 1997, Alternative Traffic Engineering Management.

\section{INTRODUCTION}

Intersections are the most important part of urban roads, because some of the efficiency, safety, speed and service levels of the road depend on the planning of the intersection. Each intersection includes both continuous traffic movement and intercrossing traffic at one or more of the intersection segments. This is the main reason for the conflict and the need for controlling traffic movements at intersections. This traffic movement can be controlled in several ways. The aim is to reduce conflict points at road intersections, reduce traffic accidents, reduce delays, degree of saturation, queue opportunities and optimize traffic flow. One part of the road that needs to be analyzed is the intersection of both the intersection of three and the intersection of four. The four-way intersection on Jalan Raya Manukan Wetan is an intersection with type 424 that brings together the flow of vehicles. The number of vehicles passing the intersection of Road Manukan Wetan continues to increase according to population growth. This is to determine the performance of the intersection ratio between the capacity and the existing traffic flow. An unsigned intersection is an intersection or a meeting in an area between two or more highway lanes with their respective intersections, and at the intersection 
points are not equipped with lights as intersection signs This is to determine the performance of the intersection ratio between the capacity and the existing traffic flow. An unsigned intersection is an intersection or a meeting in an area between two or more highway lanes with their respective intersections, and at the intersection points are not equipped with lights as intersection signs This is to determine the performance of the intersection ratio between the capacity and the existing traffic flow. An unsigned intersection is an intersection or a meeting in an area between two or more highway lanes with their respective intersections, and at the intersection points are not equipped with lights as intersection signs.

1. Problem

a. How is the performance of the intersection and road sections at the intersection of Jalan Raya Manukan Wetan (at the intersection of Jalan AMD-Jalan Buntaran) in current conditions?

b. Are traffic lights needed at the intersection and what are the alternative solutions / suggestions to solve the problem of the performance of the intersection on Jalan Raya Manukan Wetan Surabaya (at the intersection of Jalan AMD-Jalan Buntaran)?

2. Purpose

a. Evaluate the performance of intersections and road sections at the intersection of Jalan Raya Manukan Wetan (intersection of Jalan AMD and Jalan Buntarran) based on the current traffic volume.

b. Knowing is it feasible to install a traffic light, and know the best alternative to solve the problem at the intersection

\section{LITERATURE REVIEW}

\section{Previous researchers}

The following are some studies related to the Unmarked Intersection Performance Analysis:

a. Fica Rahma Pinggungan. RH, Performance Level Review of Unmarked Intersection (Case study of the four-arm intersection of Jalan Jendral Suprapto-S. Parman Bandar Lampung)

b. Irwanto, Unmarked Intersection Performance at Jalan Simpang Plaza Tugu, Purworejo Regency

c. Leni Sriharyani, Ida Hadijah, Performance Analysis of the Intersection Without Traffic (Case Study of the Way Jepara market intersection, East Lampung Regency)

d. Mala Wati Waris, Performance Analysis of Unsigned Intersections with the Guideline for Indonesian Road Capacity Method

e. Mursid Budi H, Ahmad Wicaksono, M Ruslin Anwar, Evaluation of the Performance of a NonSignalized Intersection in Jombang Regency

f. Novi Listina, Performance Analysis of the Unmarked Intersection of Jalan Raya DramagaBubulak Bogor, West Java

g. I PT GD Mahendra, P. Alit Suthanaya, Wyn Suweda, Performance Analysis of Unmarked Intersections and Roads in Denpasar City (Case Study: Unmarked Intersections JI Gatot Subroto-JI Mulawarman- JI Matara and JI. Ahmad Yani-JI Mulawarman .

h. Theresia MCA, Amrita Winaya, and Hari Setyawan, Capacity of Unsigned Intersections and Traffic Delays on JI Brigjen Katamso - JI Frontage Timur. 
i. Weka Indra Dharmawan, Devi Oktarina, Adithia Brilianto, Performance Analysis of Unmarked Intersection (Case Study: Intersection of JI Imam Bonjol-Jl Pagar Alam Kota Bandar Lampung)

j. Yogi Arisandi, Performance Analysis of Unmarked Intersection Jl Basuki Rahmat Malang City

\section{Intersection}

a. Definition of Intersection

According to Government Regulation Number 43 of 1993, an intersection is a meeting or branching of a road, either in one level or not. In other words, an intersection can be defined as two or more intersecting lines of roads and includes road and roadside facilities. Every road that spreads out and is part of the intersection is called an intersection arm.

b. Type of intersection

1. An intersection without a signal, that is, an intersection that does not use a traffic signal. At this intersection, road users must decide whether they are safe enough to pass through the intersection or must stop before passing the intersection.

2. Road intersections with signals, that is, road users can pass the intersections according to the traffic signal operation. So road users may only pass when the traffic signal shows a green colour on the intersection arm

c. Kinds of intersection

1. A meeting or intersection of a level road, is a meeting of two or more roads in one level (not in one row). There are 4 (four) types of level meeting, namely 3 (three) branch meetings or intersections, 4 (four) branch meetings or intersections, many branch meetings or intersections, roundabouts (Rotary intersections).

2. A meeting or intersection of a road that is not in level is an intersection where two or more roads meet not in one area but one of the segments is above or below another road segment.

d. Unmarked Junction Performance Measures

1. Capacity (C)

2. Degree of Saturation (DS)

3. Delay (D)

4. Chance of Queuing (QP\%)

e. Calculation of Turning Ratio and Minor Road Flow Ratio

1. Intersection current ratio $(\mathrm{PMI})$, with the formula $P M I=Q M I /$ Qtot

2. Total turnover traffic ratio (PT), with the formula $P L T=Q L T /$ Qtot.

3. The ratio between motorized vehicle traffic and non-motorized vehicles (PUM), with the formula PUM = QUM / Qtot.

f. Classification of vehicle types for unsigned intersections
1. Light Vehicle
2. Heavy Vehicles
3. Motorcycle
4. Non-Motorized Vehicles 


\section{Road Network Capacity}

Road network capacity can be interpreted as the maximum number of vehicles that can pass through the road in a period of one hour without causing traffic congestion which causes time constraints, costs, or reduces the freedom of drivers to run their vehicles. As is well known, there are several factors that must be considered in order to determine the capacity of a road segment, namely the type of road, road width, road median, side / shoulder obstacles and city size.

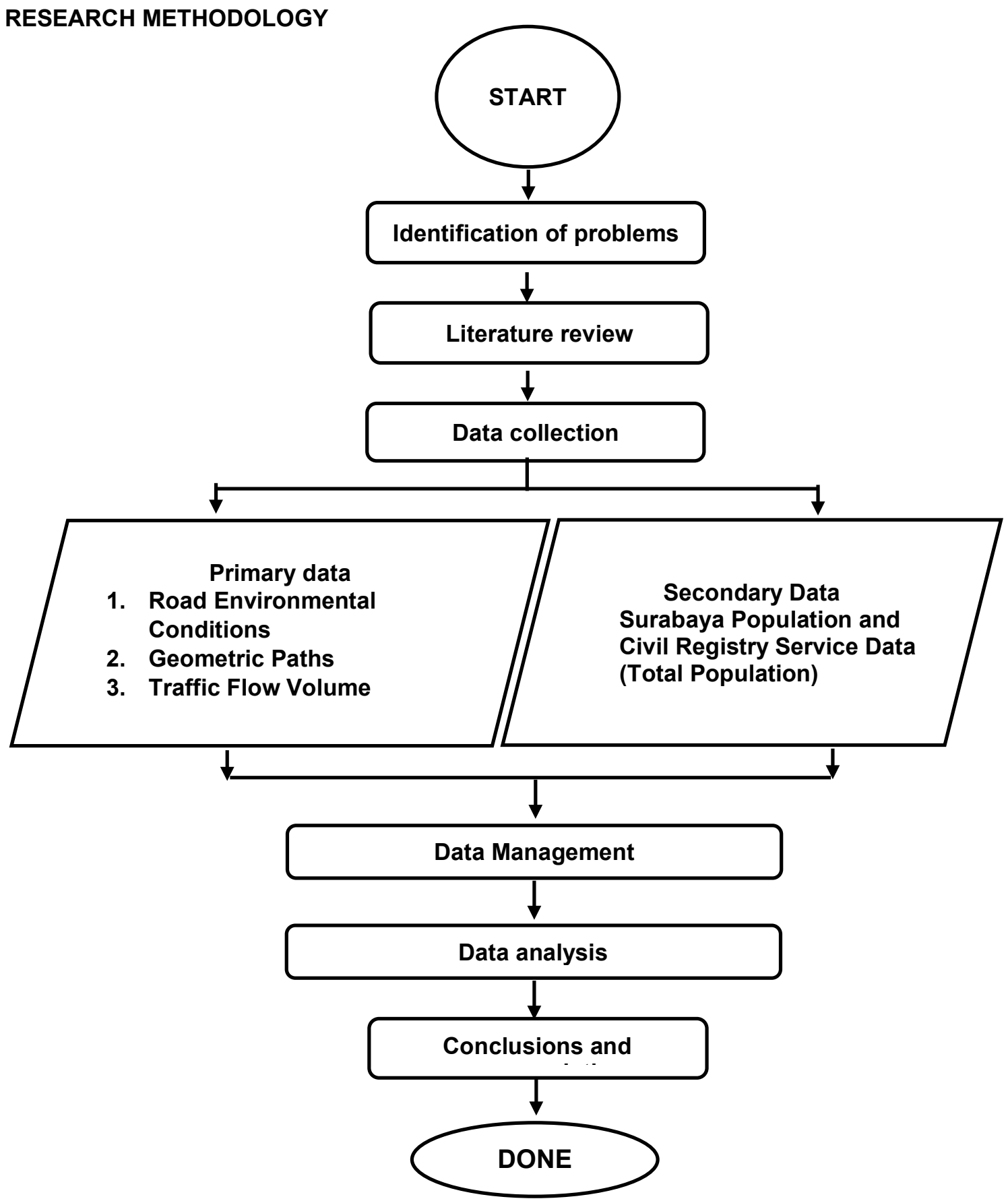

Figure 3.1 Research Flowchart 


\section{RESULT AND DISCUSSION}

\section{Simpang Profile}

Based on the field survey, data were obtained in the form of vehicle type, vehicle type, and vehicle traffic volume. The data used to analyze in this study is the peak traffic volume data in passenger car units divided by one hour (pcu / hour). The data used from the survey calculation in the field used the highest vehicle volume, namely the vehicle volume data on Monday afternoon peak hours 17.00-18.00 WIB. From the results of research in the field, most of the passing vehicles consist of two-wheeled vehicles, namely motorbikes.

Tabel 1. Traffic Data Raya Manukan Wetan Surabaya

\begin{tabular}{|c|c|c|c|c|c|c|c|c|c|c|c|c|}
\hline \multirow{3}{*}{$\begin{array}{l}\text { Vehicle } \\
\text { Type }\end{array}$} & \multicolumn{12}{|c|}{ Approach } \\
\hline & \multicolumn{3}{|c|}{ C (Buntaran) } & \multicolumn{3}{|c|}{$\begin{array}{c}\text { D (Raya Manukan } \\
\text { Wetan) }\end{array}$} & \multicolumn{3}{|c|}{ A (AMD) } & \multicolumn{3}{|c|}{$\begin{array}{c}\text { C (Raya Manukan } \\
\text { Kulon) }\end{array}$} \\
\hline & $\begin{array}{l}\text { Turn } \\
\text { Left }\end{array}$ & Straight & $\begin{array}{l}\text { Turn } \\
\text { Right }\end{array}$ & $\begin{array}{l}\text { Turn } \\
\text { Left }\end{array}$ & Straight & $\begin{array}{l}\text { Turn } \\
\text { Right }\end{array}$ & $\begin{array}{l}\text { Turn } \\
\text { Left }\end{array}$ & Straight & $\begin{array}{l}\text { Turn } \\
\text { Right }\end{array}$ & $\begin{array}{l}\text { Turn } \\
\text { Left }\end{array}$ & Straight & $\begin{array}{l}\text { Turn } \\
\text { Right }\end{array}$ \\
\hline $\begin{array}{l}\text { Light } \\
\text { vehicle }\end{array}$ & 8 & 0 & 1 & 60 & 240 & 12 & 2 & 4 & 21 & 8 & 304 & 0 \\
\hline $\begin{array}{l}\text { Heavy } \\
\text { vehcle }\end{array}$ & 1 & 0 & 0 & 5 & 20 & 8 & 0 & 1 & 4 & 2 & 324 & 0 \\
\hline Motorcycle & 392 & 4 & 52 & 188 & 1464 & 108 & 44 & 76 & 348 & 88 & 1160 & 0 \\
\hline $\begin{array}{l}\text { Non- } \\
\text { motorized } \\
\text { vihicles }\end{array}$ & 6 & 2 & 1 & 3 & 6 & 4 & 3 & 2 & 9 & 7 & 9 & 0 \\
\hline
\end{tabular}

Source: Traffic Count Results, 2020

\section{Vehicle Volume}

1. Vehicle volume at the $\mathrm{JI}$ Raya Manukan Wetan intersection

Table 2. Vehicle volume at the intersection of JI Raya Manukan Wetan

\begin{tabular}{|l|l|c|c|c|}
\hline \multirow{2}{*}{ No. } & \multirow{2}{*}{ Transportation type } & \multirow{2}{*}{ Smp Factor } & \multicolumn{2}{|l|}{ Intersection Traffic Volume } \\
\cline { 4 - 5 } & & & Vehicle / Hour & Smp / hour \\
\hline 1 & Motorcycle (MC) & 0.5 & 3924 & 1962 \\
\hline 2 & Light Vehicle (LV) & 1.0 & 660 & 660 \\
\hline 3 & Heavy Vehicle (HV) & 1.3 & 365 & 474.5 \\
\hline total & & & $3,096.5$ \\
\hline
\end{tabular}

Source: Traffic Count Results, 2020

2. Total Incoming Flow Volume from Main Road (QMA) and From Minior Road (QMI)

Table 3. Total Incoming Flow Volume

From Main Road (QMA) and From Minior Road (QMI)

\begin{tabular}{|l|c|c|}
\hline \multirow{2}{*}{ Simpang name } & \multicolumn{2}{|l|}{ Total Incoming Flow } \\
\cline { 2 - 3 } & QMA (Smp / hour) & QMI (Smp / hour) \\
\hline $\begin{array}{l}\text { Simpang Raya } \\
\text { Manukan Wetan }\end{array}$ & 2594.7 & 501.8 \\
\hline
\end{tabular}

Source: Traffic Count Results, 2020 


\section{Data Analysis}

In analyzing the capacity of the intersection of Jalan Raya Manukan Wetan, the formula is used in the guidelines for the Indonesian Road Capacity Manual (MKJI) 1997.

1. Approach Width

a. Wide Approach to Research Results
Width

b. Alternative Result Approach

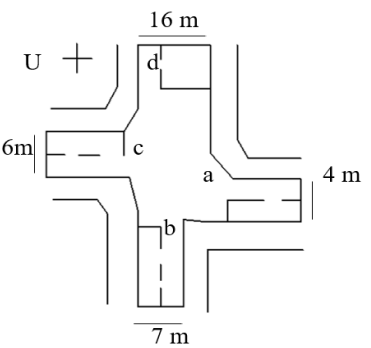

(a)

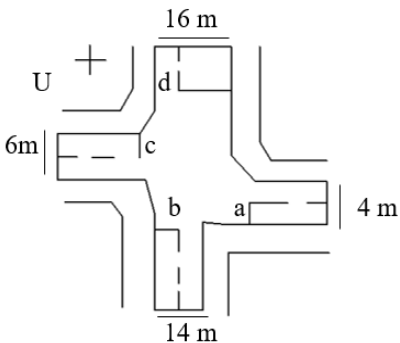

(b)

Figure 2. Personal documentation

2. Results of Comparison between Research Results and Alternative Results

Table 4. Results of Comparison between Research Results and Alternative Results

\begin{tabular}{|c|c|c|c|}
\hline No. & Component & $\begin{array}{c}\text { The } \\
\text { calculation } \\
\text { results } \\
\text { Research }\end{array}$ & $\begin{array}{c}\text { The } \\
\text { calculation } \\
\text { results } \\
\text { Alternative }\end{array}$ \\
\hline 1 & Average Approach Width (W1) (m) & 4,125 & 5 \\
\hline 2 & Capacity (C) (pcu / hour) & 3750.9 & 4131.85 \\
\hline 3 & Degree of Saturation (DS) & 0.8254 & 0.7493 \\
\hline 4 & Intersection Traffic Delay (DT1) (sec/ smp) & 9,5927 & 8,1657 \\
\hline 5 & Main Road Traffic Delay (DTMA) (sec/smp) & 7,0332 & 6,0454 \\
\hline 6 & Minor Road Traffic Delays (DTMI) (sec/ / Smp) & 22,8177 & 19,1211 \\
\hline 7 & Intersection Geometric Delay (DG) (sec/pcu) & 4,3911 & 4,9456 \\
\hline 8 & Intersection Delay (D) (sec/pcu) & 13,9838 & 13,1113 \\
\hline 9 & Chance of Queuing (QP\%) & $27.4 \%-54.3 \%$ & $22.7 \%-45.6 \%$ \\
\hline
\end{tabular}

Based on the results of research calculations at the intersection of Jalan Raya Manukan Wetan, it can be seen in table 10. The results of the calculation are as follows: the width of the approach (W1) is 4.125 meters, the actual capacity (C) is $3750.90 \mathrm{pcu} /$ hour, the degree of saturation (DS) with a value of 0.8254 , Intersection traffic delay (DT1) of $9.5927 \mathrm{sec} / \mathrm{pcu}$, main road traffic delay (DTMA) of $7.0332 \mathrm{sec} / \mathrm{smp}$, minor road traffic delay (DTMI) of 22, $8177 \mathrm{sec} / \mathrm{pcu}$, intersection geometric delay (DG) of $4.3911 \mathrm{sec} / \mathrm{pcu}$, intersection delay (D) of $13.9838 \mathrm{sec} / \mathrm{pcu}$, and queuing opportunity (QP) with a value of $27 \%-54 \%$.

Based on the results of alternative calculations in table 3 above or after changing one of the widths of the approach, the average approach width (W1) is 5 meters, the actual new capacity (C) is $4131.85 \mathrm{pcu} /$ hour, the degree of saturation (DS). ) with a value of 0.7493 , Intersection traffic delay (DT1) of $8.1657 \mathrm{sec} / \mathrm{smp}$, Main road traffic delay (DTMA) of $6.0454 \mathrm{sec} / \mathrm{smp}$, Minor road traffic delay (DTMI) of $19.1211 \mathrm{sec} / \mathrm{smp}$, intersection geometric delay (DG) of 4,9456 sec / pcu, 
intersection delay (D) of $13,1113 \mathrm{sec} / \mathrm{pcu}$, and queuing probability (QP) with a value of $22 \%-45 \%$.

\section{Summary of Comparison Results between Calculation Results and Alternative Results}

After calculating and discussing it by the researcher, this research can summarize and assess the performance of the intersection based on the $1997 \mathrm{MKJ}$ guidelines.The following is a comparison between the calculation results and the alternative results at the intersection of Jalan Raya Manukan Wetan which is tabulated in table 5.

Table 5. Manukan Wetan Highway Intersection Performance Based on Research Calculation Results and Alternative Calculation Results According to MKJI Guidelines

\begin{tabular}{|c|c|c|c|c|c|c|}
\hline No. & Component & $\begin{array}{l}\text { MKJI } \\
1997 \\
\text { standard }\end{array}$ & $\begin{array}{l}\text { The } \\
\text { calculation } \\
\text { results }\end{array}$ & $\begin{array}{l}\text { Performance } \\
\text { Notes }\end{array}$ & $\begin{array}{l}\text { Alternative } \\
\text { Results }\end{array}$ & $\begin{array}{l}\text { Performance } \\
\text { Notes }\end{array}$ \\
\hline 1 & Capacity (C) & $\begin{array}{l}3400 \text { pcu / } \\
\text { hour }\end{array}$ & 3750.90 & $\begin{array}{l}\text { Good Capacity } \\
\text { C> Standard }\end{array}$ & 4131.85 & $\begin{array}{l}\text { Good Capacity } \\
\text { C> Standard }\end{array}$ \\
\hline 2 & $\begin{array}{l}\text { Degree of } \\
\text { Saturation (DS) }\end{array}$ & 0.75 & 0.8254 & $\begin{array}{l}\text { Unstable } \\
\text { DS> Standard }\end{array}$ & 0.7493 & $\begin{array}{l}\text { Stable } \\
\text { DS < Standard }\end{array}$ \\
\hline 3 & $\begin{array}{l}\text { Intersection } \\
\text { Traffic Delays } \\
\text { (DT1) }\end{array}$ & \multirow{5}{*}{$\begin{array}{l}15 \mathrm{sec} / \\
\text { pcu }\end{array}$} & 9,5927 & $\begin{array}{l}\text { Stable } \\
\text { DT1 < Standard }\end{array}$ & 8,1657 & $\begin{array}{l}\text { Stable } \\
\text { DT1 < Standard }\end{array}$ \\
\hline 4 & $\begin{array}{l}\text { Main Road } \\
\text { Traffic Delays } \\
\text { (DTMA) }\end{array}$ & & 7,0332 & $\begin{array}{l}\text { Stable } \\
\text { DTMA } \\
<\text { Standard }\end{array}$ & 6,0454 & $\begin{array}{l}\text { Stable } \\
\text { DTMA } \\
<\text { Standard }\end{array}$ \\
\hline 5 & $\begin{array}{l}\text { Minor Road } \\
\text { Traffic Delays } \\
\text { (DTMI) }\end{array}$ & & 22,8177 & $\begin{array}{l}\text { Moderate } \\
\text { DTMl> } \\
\text { Standard }\end{array}$ & 19,1211 & $\begin{array}{l}\text { Moderate } \\
\text { DTMI> } \\
\text { Standard }\end{array}$ \\
\hline 6 & $\begin{array}{l}\text { Intersection } \\
\text { Geometric } \\
\text { Delay (DG) }\end{array}$ & & 4,3911 & $\begin{array}{l}\text { Stable } \\
\text { DG < Standard }\end{array}$ & 4,9456 & $\begin{array}{l}\text { Stable } \\
\text { DG < Standard }\end{array}$ \\
\hline 7 & $\begin{array}{l}\text { Intersection } \\
\text { Delay (D) }\end{array}$ & & 13,9838 & $\begin{array}{l}\text { Stable } \\
\mathrm{D}<\text { Standard }\end{array}$ & 13,1113 & $\begin{array}{l}\text { Stable } \\
\mathrm{D}<\text { Standard }\end{array}$ \\
\hline 8 & $\begin{array}{l}\text { Queue } \\
\text { Opportunity } \\
\text { (QP) }\end{array}$ & $23 \%-45 \%$ & $27 \%-54 \%$ & $\begin{array}{l}\text { Less } \\
\text { QP> Standard }\end{array}$ & $22 \%-45 \%$ & $\begin{array}{l}\text { Moderate } \\
\text { QP < Standard }\end{array}$ \\
\hline
\end{tabular}

Source: Research Calculation Results and Alternative Calculations

\section{Actual Capacity (C)}

The intersection capacity of Jalan Raya Manukan Wetan with the type of intersection is 424 which has an actual capacity of $3750.90 \mathrm{pcu} /$ hour, which means that it has exceeded its basic capacity of $3400 \mathrm{pcu} /$ hour. Then the intersection service can be said to be good.

\section{Degree of Saturation (DS)}

With a degree of saturation value 0.825 or more than 0.75 (DS> 0.75 ). Based on the 1997 MKJI guidelines, it is considered an unstable condition because it is more than $0.75(>0.75)$.

Delay (D)

a. Intersection traffic delays (DTI)

The delay due to traffic interaction with other movements at the intersection with a value (DT1) of $9.59 \mathrm{sec} / \mathrm{pcu}$ or less than the maximum value of $15 \mathrm{sec} / \mathrm{pcu}$, so based on the $1997 \mathrm{MKJ}$ guidelines the intersection traffic delays are in stable condition. 
b. Major road traffic delays (DTMA)

The delay due to the intersection in the main era (DTMA) is $7.03 \mathrm{sec} / \mathrm{smp}$ or less than the maximum value of $15 \mathrm{sec} / \mathrm{pcu}$, so based on the $1997 \mathrm{MKJI}$ guidelines, the main road traffic delays are in stable condition.

c. Minor road traffic delays (DTMI)

The delay due to intersections on minor roads (DTMI) is $22.81 \mathrm{sec} / \mathrm{smp}$ or more than the maximum value of $15 \mathrm{sec} / \mathrm{smp}$, so based on the $1997 \mathrm{MKJI}$ guidelines include minor road traffic delays in unstable conditions.

d. Delay geometric intersection (DG)

The geometric delay of the intersection due to deceleration of speed and acceleration when turning at the intersection (DG) is $4.39 \mathrm{sec} / \mathrm{pcu}$ or less than the maximum value of $15 \mathrm{sec} /$ pcu, so based on the $1997 \mathrm{MKJ}$ guidelines the geometric delay of the intersection is in stable condition

e. Intersection Delay (D)

The intersection delay means that the intersection traffic delay is added with the geometric delay (D-DT1 + DG), then the intersection delay (D) is $13.98 \mathrm{sec} / \mathrm{pcu}$. Then the value of this intersection delay is not more than the maximum value of $15 \mathrm{sec} / \mathrm{pcu}$, based on the 1997 MKJI guidelines, this intersection delay is in a stable condition.

f. Chance of queuing (QP\%)

The opportunity to queue at the intersection of Jalan Raya Manukan Wetan with a value of $27 \%$ $-54 \%$ is in a less and unstable condition because it has an empirical relationship with the degree of saturation at the intersection and the condition is less and unstable. The higher the degree of saturation value, the higher the chances of queuing

Based on the results of alternative calculations tabulated in table 4 , the way to maintain intersection performance is with minor geometric improvements, road widening and side friction. Yet, the intersection of Jalan Raya Manukan Wetan experiences changes in values from the results of the research calculations compare to alternative results such as the following.

\section{Actual capacity (C)}

The actual capacity increased from $3750.9 \mathrm{pcu} /$ hour to $4131.8 \mathrm{pcu} /$ hour from the research calculation.

\section{Degree of Saturation (DS)}

The degree of saturation (DS) decreased from 0.8254 to 0.7493 from the research calculation

\section{Delay (D)}

a. The intersection traffic delay (DT1) decreased from 9.59 to $8.165 \mathrm{sec} / \mathrm{pcu}$ or more stable than the researchers calculated.

b. The main road traffic delay (DTMA) decreased from $7.03 \mathrm{sec} / \mathrm{pcu}$ to $6.04 \mathrm{sec} / \mathrm{pcu}$ or more stable from the research calculation.

c. Minor road traffic delay (DTMI) decreased from $22.91 \mathrm{sec} / \mathrm{pcu}$ to $19.12 \mathrm{sec} / \mathrm{pcu}$. Due to geometric changes and a decrease in the class of side friction, although the minor road delay value is greater than the MKJI 1997 standard. But it is still relatively moderate or the condition is less stable than the research calculation. 
d. The intersection geometric delay (DG) increased from $4.39 \mathrm{sec} / \mathrm{pcu}$ to $4.945 \mathrm{sec} / \mathrm{pcu}$. Although the geometric delays of the intersection increased, it is still in a stable condition from the research calculations.

e. The intersection delay (D) of $13.98 \mathrm{sec} / \mathrm{pcu}$ decreased to $13,111 \mathrm{sec} / \mathrm{pcu}$, meaning that the intersection delay $(D)$ was still in a stable condition from the research calculations.

4. Queue Opportunity (QP)

The chances of queuing (QP) decreased by $22 \%-45 \%$, meaning that after traffic engineering and several other alternatives were carried out. Then the opportunity for queuing to experience changes that was previously in an unstable condition from $27 \%-54 \%$ to $22 \%-45 \%$ in a stable condition.

\section{CONCLUSION}

After analyzing the performance of the 4-arm unmarked intersection at Jalan Raya Manukan Wetan which refers to the MKJI 1997, the following conclusions can be drawn in this study:

1. The total volume of vehicle traffic flow (Qtot) at peak hours is $3096 \mathrm{pcu} /$ hour or less than the actual crossing capacity of $3750.9 \mathrm{pcu} /$ hour. So the performance of the intersection of Jalan Manukan Wetan is still in good performance so that it is still being optimized.

2. In optimizing the Performance of the Manukan Wetan Highway Intersection, the best condition alternative model in this study can be used the following alternatives:

a. Banning vehicles from parking or installing no parking signs and stopping to lower the class of side friction to low.

b. Widen the approach to Jalan Raya Manukan Kulon to be $14 \mathrm{~m}$

3. In this study, at the intersection of Jalan Raya Manukan Wetan, the results of the calculation have a Degree of Saturation (DS) value $<1.00$, then the Jalan Raya Manukan Wetan intersection has a traffic service level that meets the requirements or is in accordance with the guidelines for the Indonesian Road Capacity Manual ( MKJI 1997), then this intersection does not need to be installed traffic lights or Traffic Light.

\section{REFERENCES}

Fica Rahma Pinggungan RH. (2019). Overview of Performance Levels of Unmarked Intersections (Case Study of Four-Armed Intersection of Jalan Jendral Suprapto-S.Parman, Bandar Lampung).

I PT GD Mahendra, P Alit Suthanaya, Wyn Suweda, (2013). Performance Analysis of Unmarked Intersections and Roads in Denpasar City (Case Study of Unmarked Intersections JI Gatot Subroto- JI Mulawarman- J Mataram And JI. Ahmad Yani-JI Mulawarman ).

Indonesian Road Capacity Manual (MKJI). 1997.

Irwanto. (2016). Performance of the Unmarked Intersection of Jalan Tugu Plaza Simpang, Purworejo Regency.

Leni Sriharyani, Ida Hadijah, (2015). Performance Analysis of the Crossing Without Traffic (Case Study of Way Jepara Market Intersection, Lapung Timur Regency).

Limantara, A. D., Krisnawati, L. D., Winardi, S., Mudjanarko, S. W., \& Esp, C. (2017). Policy Supervision Solution to Overcome Road Congestion and City Parking Based on Smart Internet. Semin. Nas. Technol. and Engineering Inf., no. November, 1-6.

Mila Wati Waris. (2014). Performance Analysis of Unmarked Intersections Method Guidelines for Indonesian 
Road Capacity.

Mursid Budi H, Ahmad Wicaksono, M Ruslin Anwar. (2014). Performance Evaluation of Non-Signalized Intersection in Jombang Regency.

Novi Listina. (2017). Performance Analysis of the Unmarked Intersection of Jalan Raya Dramaga-Bubulak Bogor, West Java.

Theresia MCA, Amrita Winaya, Hari Setyawan, (2018). Capacity for Unmarked Intersections and Traffic Delays in Paada JI Brigjen Katamso-JI Frontage Timur.

Weka Indra Dharmawan, Devi Oktarina, Adithia Brilianto, (2018). Performance Analysis of Unmarked Intersection (Case Study: Intersection of JI Imam Bonjol -JI Pagar Alam Kota Bandar Lampung).

Yogi Arisandi, (2015). Performance Analysis of Unmarked Intersection JI Basuki Rahmat Malang City).

(C) 2020 by the authors. Submitted for possible open access publication under the terms and conditions of the Creative Commons Attribution (CC BY $\mathrm{SA}$ ) license (https://creativecommons.org/licenses/by-sa/3.0/). 